\title{
УВЕЛИЧЕНИЕ КОЛИЧЕСТВА СУДЕБНЫХ СПОРОВ И РОСТ СУДЕБНОЙ НАГРУЗКИ
}

\section{INCREASE IN THE NUMBER OF LEGAL DISPUTES AND THE GROWTH OF THE JUDICIAL LOAD}

\section{Lifintsev}

Summary: The article argues that the problem of optimizing the judicial burden, solving the problem of ensuring the right of citizens to a fair and public trial within a reasonable time, and also emphasizes that the quality of justice is directly related to the workload of judges: the ability to carefully prepare for each case, study the law, conduct trials in a calm business environment, thoughtfully, competently.

Keywords: judicial load, number of cases considered, civil proceedings, judicial practice.
A бсолютно любое правовое государство складывается из целого комплекса взаимодополняющих друг друга явлений и элементов. Одним из таких важнейших элементов, который, несомненно, играет серьезную роль в процессе осуществления правосудия, является судебная система. Сама по себе судебная власть как одна из трех ветвей государственной власти немыслима без четко структурированной иерархически организованной системы органов, ее воплощающей и реализующей. Именно воплощение и реализация судебно-властных полномочий и является важнейшей целью судебной системы как составного компонента в конфликторазрешающей деятельности на уровне государства. От эффективности судебной системы напрямую зависит то, насколько четко и отлаженно будут работать и взаимодействовать друг с другом все государственные механизмы.

Нормативное регулирование в данной сфере является крайне важным, так как в случае его нарушения появится возможность ссылаться на закон в целях защиты собственных нарушенных прав. Но на январь 2020 года имеется только совместное Постановление министерства труда и социального развития РФ и Минюста России «Об утверждении Норм нагрузки судей, судебных исполнителей и работников аппарата районных (городских) судов», который был принят еще 27 июня 1996 года. На данный момент этому постановлению уже почти 24 года. Таким образом, можно сделать вывод, что количество изменений в судебной системе России и увеличение нагрузки на суды, очень велико и внесение правок в данное постановление все равно не может целиком охва-
Лифинцев Владислав Николаевич

Аспирант, Российский государственный университет правосудия (Москва); помощник судьи, Арбитражный суд города Москвы

pavlovladislav@gmail.com

Аннотация: В статье аргументируется, что проблема оптимизации судебной нагрузки, решение проблемы обеспечения права граждан на справедливое и публичное судебное разбирательство в разумные сроки, а также подчеркивается, что качество правосудия напрямую связано с нагрузкой судей: способностью тщательно готовиться к рассмотрению каждого дела, изучать законодательство, проводить судебные процессы в спокойной деловой обстановке, вдумчиво, грамотно.

Ключевые слова: судебная нагрузка, количество рассмотренных дел, гражданское судопроизводство, судебная практика.

тить новую сложившуюся систему [1, с.136].

Нагрузки в данном постановлении указаны в виде перечисления видов работ, которые осуществляет судья. Например, имеется список, предназначенный для судьи районного суда по гражданским делам. Согласно данному списку, судья принимает исковое заявление, подготавливает дело к судебному разбирательству в порядке ст.141 ГПК, выносит различные виды определений (об обеспечении иска, о назначении дела к судебному разбирательству и так далее). Так же там указано проведение судебного заседания, передача дел по подсудности и так далее. Так же там имеются нормативы распределения времени на каждый отдельный вид дел. Например, на рассмотрение дела о расторжении брака супругов имеющих несовершеннолетних детей отводится 2,5 часа.

За последние десятилетия отношения между тремя ветвями власти в государстве (исполнительной, законодательной и судебной) претерпели существенные изменения. Во-первых, исполнительная власть и законодательная власть стали более взаимозависимыми. Сократились возможности привлечения исполнительной власти к ответственности властью законодательной. Изменилась и роль судебной власти.

Значительно увеличился объем дел и число законов, применяемых судами. Из-за резкого роста объема полномочий исполнительной власти возросло количество жалоб на ее действия в суд. Обозначилась негативная тенденция, связанная с действиями исполнительной 
власти, направленными на перекладывание ответственности и принятие соответствующих решений на власть судебную [3, с. 144].

Судебная власть стала перегруженной в контексте принятия решений по делам, в которых нет реального судебного спора, а есть желание у стороны в принятии соответствующего судебного постановления, подтверждающего либо право, либо обязанность.

Так, согласно недавно проведенным исследованиям специалистами НИУ ВШЭ, лишь чуть менее четверти российских судей (24\%) не испытывают трудностей с нагрузкой, более половины представителей судейского сообщества (62\%) перерабатывают более чем вдвое. В среднем каждый российский судья рассматривает до 180 дел и материалов в месяц, ежедневно заслушивая около 2 дел с темпом в 3-5 раз выше рекомендуемого.

Также выяснилось, что темпы работы зависят от уровня суда и разнятся в зависимости от того, в каком регионе расположен конкретный суд. Так, судья суда общей юрисдикции в среднем рассматривает чуть более 45 дел или материалов в месяц, судья арбитражного суда - 68 дел.

Судья районного суда столицы в среднем рассматривает почти 100 дел и материалов в месяц. А судьи московских арбитражных судов слушают до 180 дел в месяц - это абсолютный рекорд среди всех российских регионов. Минимально же загружены чукотские судьи.

Лишь чуть менее четверти (24\%) российских судей работают в полном соответствии со своим рабочим графиком, остальные же перерабатывают, причем 62\% перерабатывают в два и более раз, 5\% - пятикратно.

Значительно усложняет сложившуюся ситуацию и факт того, что количество дел и материалов в судах с каждым годом возрастает. Так, согласно статистике судебного департамента Верховного Суда РФ, в период с 2017 г. по 2019 г. в судах общей юрисдикции оно увеличилось на 13\%. Объем рассмотренных дел в арбитражных судах за тот же период вырос почти на 22\% ежегодно.

Численность судей же за представленный период практически не изменилась. Несмотря на то, что в 20172019 гг. число судейских ставок увеличилось и приблизилось к отметке в 30 тыс., фактическая численность судей даже понизилась - их штат был укомплектован менее чем на $87 \%$ [5, с. 87]

Основную нагрузку на суды составляют гражданские дела, в 2018 году судами рассмотрено 17,3 млн дел, в 2019 году уже порядка 19,6 млн гражданских дел (для сравнения - в 2019 году рассмотрено более 7 млн дел об административных правонарушениях, 749 тыс. уго- ловных дел, арбитражными судами рассмотрено 1,9 млн экономических споров). В подавляющем большинстве случаев судами принимается решение об удовлетворении требований истцов, что зачастую связано с тем, что в данных исках отсутствует как таковой спор о праве между сторонами и суд используется в качестве механизма принуждения ответчика к выполнению взятых на себя обязанностей.

Ярким примером являются иски налоговых органов к гражданам, где удовлетворяется почти 100 процентов, ответчик обычно в суд не является и не предпринимает каких-либо процессуальных действий. Кроме того, средняя цена таких исков несопоставима стоимости работы судьи и аппарата суда, что приводит к парадоксальной ситуации: государство несет затраты по финансированию работы должностных лиц налоговых органов, судебной системы, что в сумме значительно превышает цену самого иска, оставляя государство фактически в убытке.

Со стремительным возрастанием объема рассматриваемых дел сам процесс судопроизводства заметно ускорился и приобрел характер конвейера [2, с. 128].

Адаптация судей к возросшим нагрузкам чаще всего осуществляется посредством сокращения времени, отведенного для рассмотрения одного дела. В связи с нехваткой времени «вместо того чтобы посвящать заседанию полчаса, его проводят за 15 минут».

Данная негативная тенденция уже сейчас привела к тому, что судьи все чаще стремятся поскорее завершить начатый процесс рассмотрения дела и вынести решение по заранее отработанному шаблону. Однако уже сейчас можно принять ряд мер, которые бы значительно помогли сгладить существующие противоречия и наметить пути разрешения сложившихся проблем. В первую очередь необходимо увеличить численность судейского корпуса. Так, эксперты отмечают, что штатную численность судей только районного уровня нужно в 2,1 раза.

Некоторые проблемы можно вполне можно решить даже и без увеличения численности судей. Целый ряд процессуальных функций, выполняемых сегодня судьями, можно передать их помощникам, чтобы они решали чисто технические моменты (к примеру, своим решением возвращали исковое заявление, в том случае, если государственная пошлина за подачу данного заявления не была уплачена).

Снизить нагрузку и повысить открытость судов позволит новый механизм пересмотра судебных решений в судах общей юрисдикции. Когда апелляция и кассация проходили в одном регионе, это могло порождать сомнения в объективности рассмотрения того или иного дела, а теперь решения будут проверять межрегиональ- 
ные суды. По такой схеме уже успешно работают арбитражные суды.

К актуальным механизмам оптимизации судебной нагрузки относятся мероприятия, направленные на расширение сферы применения упрощенного и приказного производства, досудебных мер урегулирования споров, третейского разбирательства и отраслевого арбитража.

В упрощенных процедурах сегодня уже рассматривается более $75 \%$ гражданских и административных дел в судах общей юрисдикции и почти $60 \%$ дел в арбитражных судах. Кроме расширения сферы применения упрощенных процедур, некоторые страны также прорабатывают возможности использования искусственного интеллекта для рассмотрения гражданских и административных дел по бесспорным требованиям, в том числе в приказном и упрощенном производстве. Такая работа может проводиться без судебного заседания путем обмена электронными документами, она не связана с анализом правоотношений сторон и в большей степени носит технический характер.

Пока сохраняется низкая эффективность использования досудебных мер урегулирования спора. Так, процедура медиации в прошлом году применена при рассмотрении 1,2 тыс. гражданских дел и всего по 11 экономическим спорам. В целях развития мирного внесудебного урегулирования споров и альтернативных процедур Верховным судом разработан и введен в действие институт судебного примирения, который направлен как на снижение уровня конфликтности в обществе, так и на уменьшение судебной нагрузки.

Также в международной практике эффективным механизмом снижения нагрузки на суды является введение рациональной по размеру государственной пошлины. Это позволяет снизить количество «безнадежных» или сомнительных исков, предъявляемых недобросовестными участниками гражданского оборота, а также способствует актуализации досудебного урегулирования споров [4, с. 24].

Оценка роли государственной пошлины в обеспечении эффективности судебной системы требует профессионального и глубокого взгляда. В России выплачиваемая истцом государственная пошлина во много раз меньше издержек по отправлению правосудия, что делает для сторон обращение в суд крайне выгодным. Низкая «цена» правосудия приводит к высокому спросу и неконтролируемому росту нагрузки на судебную систему.

Основываясь на данном выводе, европейские страны устанавливают высокую государственную пошлину для гражданских исков, используя различные подходы к установлению ее размера. Так, в Швеции и Португалии размер является неизменным, а в Германии, Нидерландах и Италии размер государственной пошлины зависит от цены иска.

Решение проблемы высокой нагрузки на судей невозможно без утверждения научно обоснованных нормативов нагрузки и формирования судейского корпуса на их основе. Попытки разработки таких нормативов предпринимаются с 2004 года, сложность возникает с критериями, которые должны учитывать не только количество дел, рассматриваемых судьей ежедневно, но и время, необходимое для анализа материалов дела с учетом особенностей процедуры подготовки дела к судебному разбирательству, необходимости проведения очного заседания, подготовки мотивированного решения и так далее. В целом консенсус относительно утверждения норм нагрузки и их закрепления на уровне федерального законодательства не найден.

Одним из последних ключевых решений в вопросе повышения эффективности стало создание по экстерриториальному принципу кассационных и апелляционных судов. За прошедший период кассационными судами общей юрисдикции по гражданским и административным делам удовлетворено 15\% жалоб, что почти в четыре раза больше, чем судами общей юрисдикции в 2019 году, когда президиумы судов областного звена в порядке выборочной кассации удовлетворили только 4\% жалоб. В уголовном судопроизводстве по правилам сплошной кассации удовлетворено $38 \%$ жалоб. Результаты работы апелляционных судов общей юрисдикции и апелляционного военного суда за указанный период практически полностью соответствуют результатам рассмотрения апелляционных жалоб Верховным судом. Высокие показатели работы свидетельствуют о том, что новые суды стали эффективным институтом внутреннего контроля качества судебных решений, что позитивно сказывается на работе всей судебной системы.

Внедрение электронного правосудия и цифровое обеспечение судопроизводства также становится эффективным механизмом оптимизации работы судебной системы, который позволяет упростить документооборот с последовательным переходом от электронного к цифровому способу передачи данных, обеспечить безопасное хранение данных, упростить процесс как для судей, так и для физических лиц и организаций. Основой электронного правосудия стала ГАС «Правосудие», на базе которой разрабатывается суперсервис «Правосудие-онлайн», который уже объединит в себе актуальные современные технологии [5, с. 89].

Бесспорно, что технологическая модернизация судебной системы позволит усовершенствовать организацию судебного процесса и позитивно отразится на снижении нагрузки на судей. 


\section{ЛИТЕРАТУРА}

1. Аникеев И.В., Шумов П.В. Эффективность судебного процесса // Бюллетень науки и практики. 2019. №6. URL: https://cyberleninka.ru/article/n/effektivnostsudebnogo-protsessa (дата обращения: 18.11.2020).

2. Бурдина Е.В., Петухов Н.А. Эффективность использования судебных ресурсов и проблемы организации судов // Экономическая политика. 2018. №2, с. 126-147 URL: https://cyberleninka.ru/article/n/effektivnost-ispolzovaniya-sudebnyh-resursov-i-problemy-organizatsii-sudov (дата 0бращения: 18.11.2020).

3. Бурдина Е.В., Петухов Н.А. Служебная нагрузка на судей: Проблемы определения, оценки, управления: Монография / Под ред. В.В. Ершова. - М.: Рос. Гос. Ун-т правосудия, 2017. - 236 c. URL: https://search.rsl.ru/ru/record/01009510704 (дата обращения: 18.11.2020).

4. Макарова-Землянская, А.А. Оптимизация и законодательное определение норм судебной нагрузки судей в районных судах / А.А. Макарова-Землянская. — Текст: непосредственный // Юридические науки: проблемы и перспективы: материалы IX Междунар. науч. конф. (г. Казань, июнь 2020 г.). — Казань: Молодой ученый, 2020. — C. 23-29. URL: https://moluch.ru/conf/law/archive/372/15851/ (дата обращения: 18.11.2020).

5. Рахманова М.А., Шумов П.В. Нагрузка на судей и качество правосудия // Бюллетень науки и практики. 2019. №10. URL: https://cyberleninka.ru/article/n/ nagruzka-na-sudey-i-kachestvo-pravosudiya (дата обращения: 18.11.2020).

( Лифинцев Владислав Николаевич (pavlovladislav@gmail.com).

Журнал «Современная наука: актуальные проблемы теории и практики»

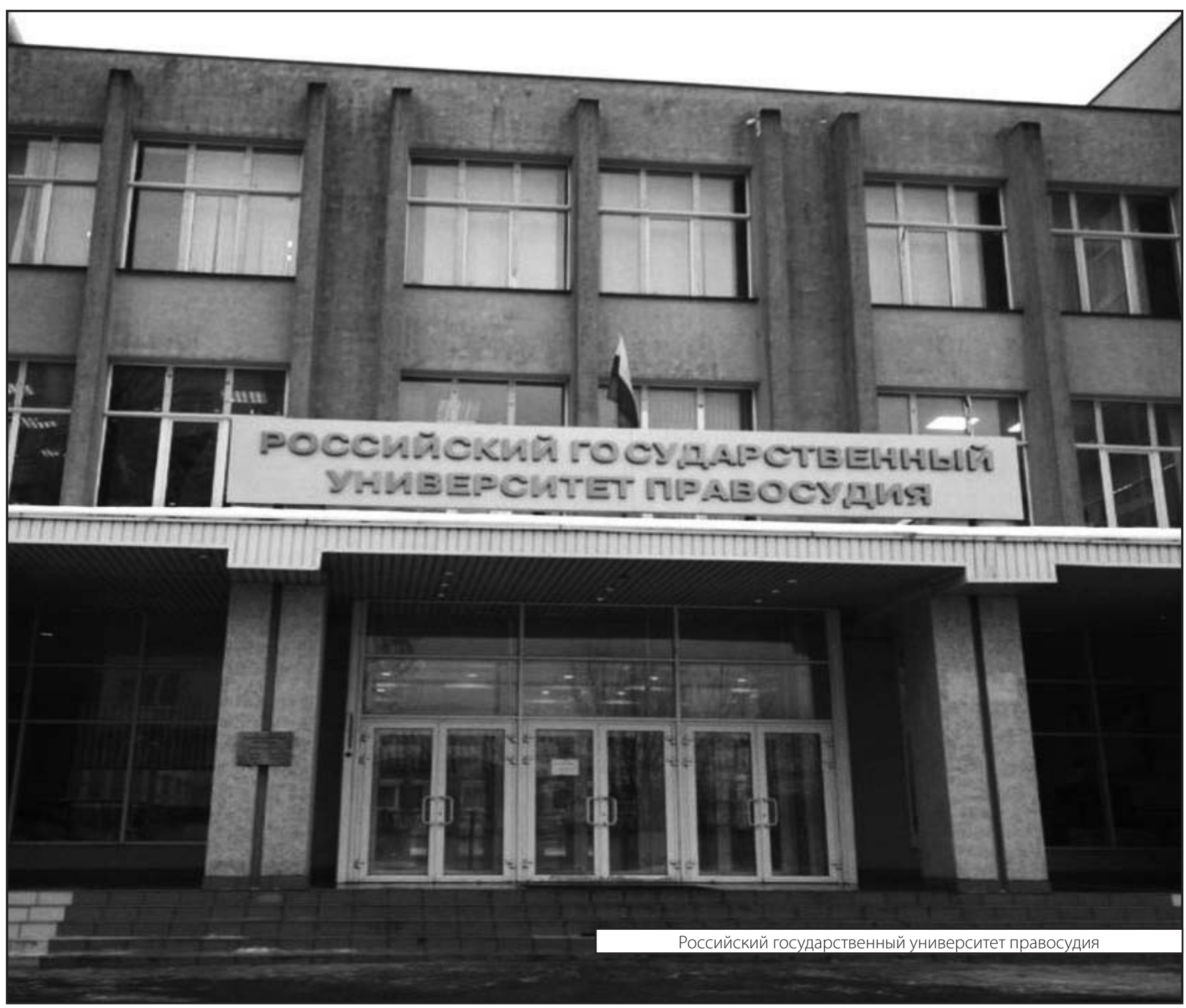

